\title{
Performance of ICU ventilators during noninvasive ventilation with large leaks in a total face mask: a bench study ${ }^{* * * *}$
}

\author{
Desempenho de ventiladores de UTI durante ventilação não invasiva com \\ grandes vazamentos em máscara facial total: estudo em simulador mecânico \\ Maria Aparecida Miyuki Nakamura, Eduardo Leite Vieira Costa, \\ Carlos Roberto Ribeiro Carvalho, Mauro Roberto Tucci
}

\begin{abstract}
Objective: Discomfort and noncompliance with noninvasive ventilation (NIV) interfaces are obstacles to NIV success. Total face masks (TFMs) are considered to be a very comfortable NIV interface. However, due to their large internal volume and consequent increased $\mathrm{CO}_{2}$ rebreathing, their orifices allow proximal leaks to enhance $\mathrm{CO}_{2}$ elimination. The ventilators used in the $\mathrm{ICU}$ might not adequately compensate for such leakage. $\mathrm{ln}$ this study, we attempted to determine whether ICU ventilators in NIV mode are suitable for use with a leaky TFM. Methods: This was a bench study carried out in a university research laboratory. Eight ICU ventilators equipped with NIV mode and one NIV ventilator were connected to a TFM with major leaks. All were tested at two positive end-expiratory pressure (PEEP) levels and three pressure support levels. The variables analyzed were ventilation trigger, cycling off, total leak, and pressurization. Results: Of the eight ICU ventilators tested, four did not work (autotriggering or inappropriate turning off due to misdetection of disconnection); three worked with some problems (low PEEP or high cycling delay); and one worked properly. Conclusions: The majority of the ICU ventilators tested were not suitable for NIV with a leaky TFM.
\end{abstract}

Keywords: Ventilators, mechanical; Positive-pressure Respiration; Noninvasive ventilation; Equipment safety; Equipment failure; Masks.

\section{Resumo}

Objetivo: 0 desconforto e a falta de adaptação às interfaces de ventilação não invasiva (VNI) são obstáculos ao sucesso da VN1. A máscara facial total (MFT) é uma interface de VN1 considerada muito confortável. No entanto, devido a seu grande volume interno e, consequentemente, ao aumento da reinalação de $\mathrm{CO}_{2}$, a MFT tem orifícios que permitem vazamentos proximais para melhorar a eliminação de $\mathrm{CO}_{2}$. É possível que os ventiladores usados na UTI não compensem esse vazamento adequadamente. Neste estudo, buscamos determinar se ventiladores de UTl com módulo de VNl podem ser usados com MFT com grandes vazamentos. Métodos: Estudo em simulador mecânico conduzido em um laboratório universitário de pesquisa. Oito ventiladores de UTl equipados para realizar $\mathrm{VN1}$ e um ventilador específico para VNI foram conectados a uma MFT com grandes vazamentos. Todos foram testados com dois níveis de positive end-expiratory pressure (PEEP, pressão expiratória final positiva) e três níveis de pressão de suporte. As variáveis analisadas foram disparo do ventilador, ciclagem, vazamento total e pressurização. Resultados: Dos oito ventiladores de UTl, quatro não funcionaram (autodisparo ou desligamento inapropriado por detecção incorreta de desconexão), três funcionaram com alguns problemas (valores baixos de PEEP ou grande atraso na ciclagem do ventilador) e apenas um funcionou adequadamente. Conclusões: A maioria dos ventiladores de UT1 testados mostrou-se inadequada para VN1 com MFT com grandes vazamentos.

Descritores: Ventiladores mecânicos; Respiração com pressão positiva; Ventilação não invasiva; Segurança de equipamentos; Falha de equipamento; Máscaras.

\footnotetext{
*Study carried out in Laboratório de Investigação Médica 09 (LIM 09, Laboratory for Medical Research 09), Department of Pulmonology, Heart Institute, University of São Paulo School of Medicine Hospital das Clínicas, São Paulo, Brazil.

Correspondence to: Mauro R. Tucci. Laboratório de Investigação Médica 09 (LIM-09), University of São Paulo School of Medicine, Avenida Dr. Arnaldo, 455, $2^{\circ}$ andar, sala 2144, CEP 01246-903, São Paulo, SP, Brasil.

Tel. 5511 3061-7361. E-mail: mrotucci@gmail.com

Financial support: This study received financial support from the Fundação de Amparo à Pesquisa do Estado de São Paulo (FAPESP, São Paulo Research Foundation) and the Financiadora de Estudos e Projetos (FINEP, Brazilian Financing Agency for Studies and Projects).

Submitted: 17 September 2013. Accepted, after review: 5 April 2014.

${ }^{* *}$ A versão completa em português deste artigo está disponivel em www.jornaldepneumologia.com.br
} 


\section{Introduction}

Noninvasive ventilation (NIV) has been used successfully in order to manage respiratory failure of different etiologies. ${ }^{(1)}$ Adherence to treatment is a major concern and has a profound impact on NIV success. In acute respiratory failure, for example, $40-60 \%$ of NIV trials fail due to mask discomfort and patient noncompliance. ${ }^{(2-4)}$

The total face mask (TFM) is an alternative interface designed to increase patient tolerance. It covers the entire face, delivering effective ventilation via nasal and oral routes. By means of its increased contact surface with the skin, it also minimizes gas leakage whilst avoiding pressure sores to the face. ${ }^{(5-7)}$ However, TFM has the disadvantage of having a large internal volume $(875 \mathrm{~mL}){ }^{(8)}$ Therefore, in order to minimize $\mathrm{CO}_{2}$ rebreathing, the mask has two built-in exhalation ports that allow air leakage. ${ }^{(5,9,10)}$ These intentional air leaks are often adequately compensated by NIV ventilators but might not be handled as well by $1 C U$ ventilators. ${ }^{(11)}$

The main hypothesis of our study was that ICU ventilators do not perform adequately with TFM with large air leaks. We evaluated the performance of ICU ventilators in delivering NIV via TFM with large air leaks on a bench model and compared the results obtained with a mechanical ventilator dedicated for NIV.

\section{Methods}

This was an experimental study conducted in 2008 in the Laboratory for Medical Research 09, specializing in Pulmonology, at the University of São Paulo School of Medicine, in the city of São Paulo, Brazil.

The NIV model (Figure E1, available online at http://www.jornaldepneumologia.com.br/ imagebank/images/jbp_v40n3_suplemment. pdf) was adapted from previously described models $^{(12,13)}$ and consisted of a two-chamber test lung (TTL 2600; Michigan Instruments, Grand Rapids, MI, USA) partially connected by a lift bar. The first chamber (drive chamber) was connected to the drive ventilator and, during the inspiratory phase, was insufflated, moving the second chamber (chest chamber) together and producing a negative pressure in its interior, which was transmitted to a second one-chamber test lung (Takaoka, São Paulo, Brazil). This simulator consists of a bellows device in a rigid box, the bellows representing the "lung", and the space between the bellows and the box representing the pleural space with direct communication with the chest chamber. The "lung" was connected to a mannequin head made of PVC. A TFM (Philips Respironics, Murryville, PA, USA) was attached to the mannequin head and connected to the test ventilator. The mechanical lung model compliance was $50 \mathrm{~mL} / \mathrm{cmH}_{2} \mathrm{O}$ at an inspiratory volume of $500 \mathrm{~mL}$.

Two pressure transducers (Valydine, Northridge, CA, USA) were connected to the model (Figure E1): one for proximal pressure (between the mask and the proximal pneumotachograph) and one for pleural pressure (between the two-chamber test lung and the one-chamber test lung). The flow was measured with two pneumotachographs (Hans-Rudolph, Kansas City, MO, USA): one for proximal flow (between the proximal pressure transducer and the $Y$ connector from the ventilator circuit) and one for distal flow (between the upper airway of the mannequin and the one-chamber test lung). The resistance of the proximal pneumotachograph varied with the flow values. For flows of $0.5 \mathrm{~L} / \mathrm{s}, 1.0 \mathrm{~L} / \mathrm{s}$, $2.0 \mathrm{~L} / \mathrm{s}$, and $3.0 \mathrm{~L} / \mathrm{s}$, resistance was $1.29 \mathrm{cmH}_{2} 0$ . $\mathrm{L}^{-1} \cdot \mathrm{s}^{-1}, 1.44 \mathrm{cmH}_{2} \mathrm{O} . \mathrm{L}^{-1} \cdot \mathrm{s}^{-1}, 1.91 \mathrm{cmH}_{2} \mathrm{O}$. $\mathrm{L}^{-1} \cdot \mathrm{s}^{-1}$, and $2.40 \mathrm{cmH}_{2} \mathrm{O} \cdot \mathrm{L}^{-1} \cdot \mathrm{s}^{-1}$, respectively. The analogical signals from the transducers were recorded at $200 \mathrm{~Hz}$ and analyzed off-line with a customized Labview software program (National Instruments, Austin, TX, USA).

A Newport e500 ventilator (Newport Medical Instruments, Costa Mesa, CA, USA) was used in order to provide the inspiratory effort for the NIV model. Respiratory rate was 12 breaths/min in pressure control mode. Inspiratory time was $1.0 \mathrm{~s}$, driving pressure was $17 \mathrm{cmH}_{2} 0$, positive end-expiratory pressure (PEEP) was $0 \mathrm{cmH}_{2} \mathrm{O}$, and inspiratory slope was +2 , developing a tidal volume in the mechanical lung model of $300 \mathrm{~mL}$ and an airway occlusion pressure after $0.1 \mathrm{~s}$ $\left(\mathrm{P}_{0.1}\right)$ of $3.4 \mathrm{cmH}_{2} \mathrm{O}$.

\section{Ventilators tested}

One NIV ventilator (BiPAP Vision; Philips Respironics) and eight ICU ventilators, all equipped with noninvasive mode, were tested (Table E1, available online at http://www. jornaldepneumologia.com.br/imagebank/images/ jbp_v40n3_suplemment.pdf): Puritan Bennett 840 (Covidien, Boulder, CO, USA); Servo-i (Maquet, 
Solna, Sweden); Vela (Viasys Healthcare, Palm Springs, CA, USA); Savina (Drägerwerk AG \& Co., Lübeck, Germany); Esprit (Philips Respironics); GALILEO Gold (Hamilton Medical, Rhäzuns, Switzerland); Horus (Taëma, Anthony, France); and e500 (Newport Medical Instruments).

Whenever available, the pressure trigger was used and set to the most sensitive level that did not result in autotriggering. When the pressure trigger was unavailable or autotriggering was unavoidable, we used the flow trigger. When adjustable, inspiratory rise time was set, initially, at $50 \%$ of the maximum value, expiratory threshold was set at 25\% of peak inspiratory flow (PIF), and maximum inspiratory time was set at $1.5 \mathrm{~s}$. The evaluations were performed using pressure support model, with PEEPs of 5 $\mathrm{cmH}_{2} \mathrm{O}$ (PEEP5) and $10 \mathrm{cmH}_{2} \mathrm{O}$ (PEEP10), each with three different pressure support levels: 5 $\mathrm{cmH}_{2} \mathrm{O}$ (PS5); $10 \mathrm{cmH}_{2} \mathrm{O}$ (PS10); and $15 \mathrm{cmH}_{2} \mathrm{O}$ (PS15). Initially, each ventilator was tested with a sealed facial mask in order to verify the NIV functionality of the ventilator. The TFM was subsequently tested with the two exhalation ports open to allow air to escape, as recommended by the manufacturer. ${ }^{(5)}$

\section{Measured variables}

First, we evaluated whether each ventilator worked properly with the TFM. The "no operation" of the ventilator was defined as the presence of constant autotriggering or of the inspiratory flow turning off (misinterpretation of disconnection due to massive leakage) even after trying different settings of triggering and inspiratory rise time. If the ventilator worked, we recorded the additional adjustments necessary to make it work properly.

We measured the following variables (Figure 1): proximal inspiratory pressure (PIP) at the end of the inspiratory phase, in $\mathrm{cmH}_{2} \mathrm{O}$, measured at the proximal sensor; PEEP, in $\mathrm{cmH}_{2} \mathrm{O}$; inspiratory leakage, in $\mathrm{L} / \mathrm{s}$, determined by the difference between proximal flow and distal flow at PIF; expiratory leakage, in $\mathrm{L} / \mathrm{s}$, by measuring proximal flow at the end of the expiratory phase; PIF, in $\mathrm{L} / \mathrm{s}$; tidal volume, in $\mathrm{L}$, calculated by the integration of the flow signal from the distal flow transducer; trigger delay, in ms, determined by the time elapsed between the onset of inspiratory effort (in pleural pressure) and the onset of inspiratory flow; cycling-off delay, in ms, measured by the

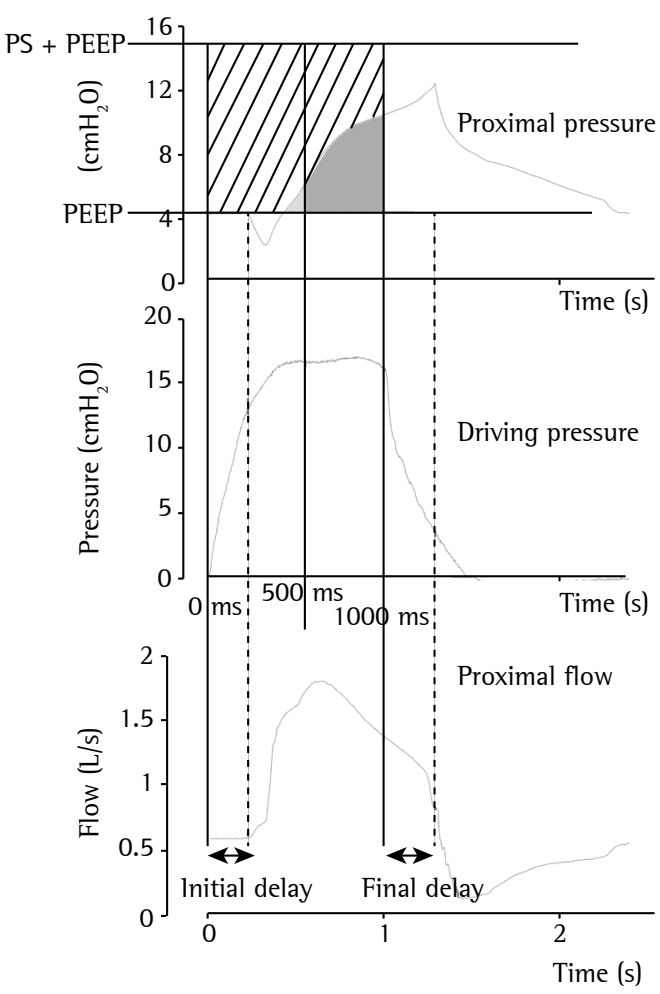

Figure 1 - Representation of the variables measured. Pressure (upper) and flow (lower) tracings of a hypothetical measurement with positive end-expiratory pressure (PEEP) of $5 \mathrm{cmH}_{2} \mathrm{O}$ and pressure support (PS) of $10 \mathrm{cmH}_{2} \mathrm{O}$. In the middle, tracing of the pressure for the drive ventilator. The upper tracing shows the inspiratory pressure-time product at $500 \mathrm{~ms}$ (PTP500; light gray area) and at $1 \mathrm{~s}$ (PTPt; dark gray area plus light gray area), both expressed in percentage of ideal area (line-shaded areas).

time from the end of the driving inspiratory effort to the end of the ventilator inspiratory flow; and inspiratory pressure-time product at $500 \mathrm{~ms}$ and at $1 \mathrm{~s}$ (PTP500 and PTPt, respectively), determined by computing the area under the pressure-time curve between the onset of inspiratory effort and these two times.

\section{Statistical analysis}

For each experimental condition, the software calculated a representative mean cycle through a point-by-point averaging of five cycles. Data for each variable are shown as one value (from the mean cycle) for each condition. Data for the various conditions are shown as mean \pm SD.

The cycles were very stable, and the variances for each variable were negligible; therefore, in 
our analysis, we did not use formal statistical hypothesis tests but a nominal comparison of the values of each mean cycle, such as in other similar studies. ${ }^{(13,14)}$ Because of the low variability of the NIV mechanical model, any clinically relevant difference in the measurements would certainly result in a difference of more than 2.8 times the measurement error (standard deviation of various cycles of one condition). ${ }^{(15)}$ The calculated values (2.8 times the measurement error) were as follows: tidal volume, $0.020 \mathrm{~L}$; PIP, $0.17 \mathrm{cmH}_{2}$ 0; PEEP, $0.15 \mathrm{cmH}_{2} 0$; PTP500, 4.3\%; PTPt, 2.5\%; PIF, $0.05 \mathrm{~L} / \mathrm{s}$; expiratory leak, $0.03 \mathrm{~L} / \mathrm{s}$; trigger delay, $9.7 \mathrm{~ms}$; and cycling-off delay, $7.5 \mathrm{~ms}$.

\section{Results}

The NIV ventilator and only four of the ICU ventilators equipped with NIV mode worked with the TFM: Horus, Vela, e500, and Servo-i (Table 1). Of these, all but the Servo-i had problems to trigger or to cycle off. The main problems in the other ventilators, which were considered to be non-operational, were the misinterpretation of disconnection and autotriggering. With the sealed oronasal mask (i.e., in the absence of significant system leakage), all ventilators worked well.

In all ICU ventilators, except for the Horus, we needed to turn the NIV mode on. For the Horus, e500, and Vela to work in some settings, we needed to adjust the expiratory trigger sensitivity, the inspiratory pressure slope, or the inspiratory sensitivity.

The Horus ventilator did not work in NIV mode. Using the default "invasive mode", we had to set it to pressure support mode, with its expiratory cycling threshold and inspiratory pressure-slope adjusted to maximum $(30 \mathrm{~L} / \mathrm{min}$ and $150 \mathrm{cmH}_{2} \mathrm{O} / \mathrm{s}$, respectively). Inspiratory trigger

Table 1 - Performance of the ventilators tested ${ }^{\text {a }}$ with the total face mask and the major problems observed.

\begin{tabular}{|c|c|c|c|}
\hline Ventilator & Proper operation & Cause of no operation & Problems during operation \\
\hline BiPAP Vision & Yes & & \\
\hline Puritan Bennett $840^{\mathrm{b}, \mathrm{c}}$ & No & AT & \\
\hline Savina ${ }^{b, d}$ & No & AT & \\
\hline GALILEO Gold ${ }^{\mathrm{b}, \mathrm{e}}$ & No & FTO & \\
\hline Servo-i $i^{b, f}$ & Yes & & $\begin{array}{l}\text { Premature cycling at PEEP5 and } \\
\text { PS5 and at PEEP10 and PS5 }\end{array}$ \\
\hline$e 500^{b, e}$ & No & $\begin{array}{c}\text { FT0 } \\
\text { (nonoperational at PEEP10) }\end{array}$ & $\begin{array}{l}\text { LCF at PEEP } 5 \text { and } \\
\text { the } 3 \text { PS settings }\end{array}$ \\
\hline Espritt ${ }^{\mathrm{b}, \mathrm{g}}$ & No & AT, FTO & \\
\hline Horus (NIV deactivated) & No & $\begin{array}{c}\text { FT0 } \\
\text { (nonoperational at PEEP5) }\end{array}$ & $\begin{array}{l}\mathrm{CIT} \text { and } \mathrm{LCF} \text { at PEEP10 } \\
\text { and the } 3 \text { PS settings }\end{array}$ \\
\hline Horus & No & AT & \\
\hline Vela ${ }^{b, h}$ & No & & $\mathrm{CIT}$ \\
\hline \multicolumn{4}{|c|}{ 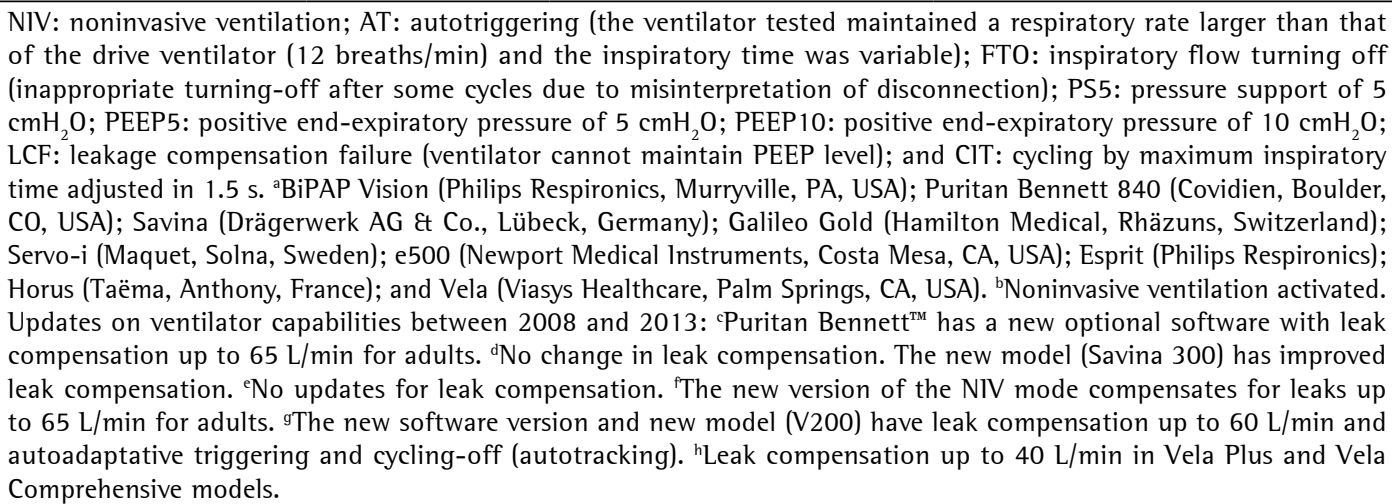 } \\
\hline
\end{tabular}


sensitivity could not be properly adjusted with the pressure-trigger option and worked only within a narrow range with the flow-trigger option (approximately $1.7 \mathrm{~L} / \mathrm{min}$ ).

The e500 inspiratory pressure slope was set to automatic mode, as was the expiratory cycling threshold at 50\% of peak flow. To avoid autotriggering, it was necessary to set the pressure trigger at values close to $-3.2 \mathrm{cmH}_{2} \mathrm{O}$.

The Vela NIV mode has an automatic selection of inspiratory triggering sensitivity. Expiratory cycling threshold had to be set at maximum (30\% of peak flow). However, when PEEP was set at $10 \mathrm{cmH}_{2} \mathrm{O}$ and pressure support was set at 15 $\mathrm{cmH}_{2} \mathrm{O}$, there was a high inspiratory cycling-off delay, creating large tidal volumes that exceeded the lung model capacity.

The Servo-i worked properly. Its NIV mode has automatic inspiratory triggering sensitivity. The inspiratory pressure slope was adjusted to $50 \%$ of maximum ( $0.2 \mathrm{~s}$ ), and the expiratory cycling threshold was set at 25\% of peak flow.

The inspiratory flow slope of the NIV ventilator (BiPAP Vision) was adjusted to 50\% of maximum (0.2 s). The inspiratory-triggering and expiratorytriggering sensitivity were automatic.

Regarding PEEP and expiratory leakage, the Servo-i, Vela, and BiPAP Vision compensated for the TFM leaks during exhalation, maintaining PEEP values close to the set values (Figure 2). The mean flows delivered by these ventilators in order to compensate for leaks during exhalation were $0.65 \pm 0.12 \mathrm{~L} / \mathrm{s}$ and $0.89 \pm 0.16 \mathrm{~L} / \mathrm{s}$ for PEEP5 and PEEP10, respectively. The e500 and Horus compensated for the leakage poorly and therefore were not able to maintain the target PEEP (Figure 2). The maximum leakagecompensation flows for the e 500 and Horus were, respectively, $0.52 \pm 0.01 \mathrm{~L} / \mathrm{s}$ (PEEP5 with leakage compensation option switched on) and $0.41 \pm 0.01 \mathrm{~L} / \mathrm{s}$ (PEEP10).

The Horus ventilator had the lowest PIP at the mask (Figure E2, available online at http:// www.jornaldepneumologia.com.br/imagebank/ images/jbp_v40n3_suplemment.pdf). All of the other ventilators reached similar PIPs. The BiPAP Vision presented with the highest PTP500 and PTPt values (Figure 3). The e500 and Horus had the lowest values for PTP500.

The PIF values increased in parallel with increases in inspiratory pressures (Figure 4), and the volume of leaks increased in parallel with increases in PEEP and pressure support. The mean values of PIF for all ventilators were $1.69 \pm 0.31 \mathrm{~L} / \mathrm{s}, 2.07 \pm 0.26 \mathrm{~L} / \mathrm{s}$, and $2.36 \pm$ $0.31 \mathrm{~L} / \mathrm{s}$, respectively, at PS5, PS10, and PS15. The highest PIFs were reached by the BiPAP Vision and e500 $(2.39 \pm 0.32 \mathrm{l} / \mathrm{s}$ and $2.14 \pm$ $0.32 \mathrm{~L} / \mathrm{s}$, respectively). The Servo-i and the Vela ventilators had intermediate values $(2.00 \pm 0.32$ $\mathrm{L} / \mathrm{s}$ and $1.82 \pm 0.33 \mathrm{~L} / \mathrm{s}$, respectively), and the smallest PIFs were attained by the Horus $(1.60$ $\pm 0.29 \mathrm{~L} / \mathrm{s})$.

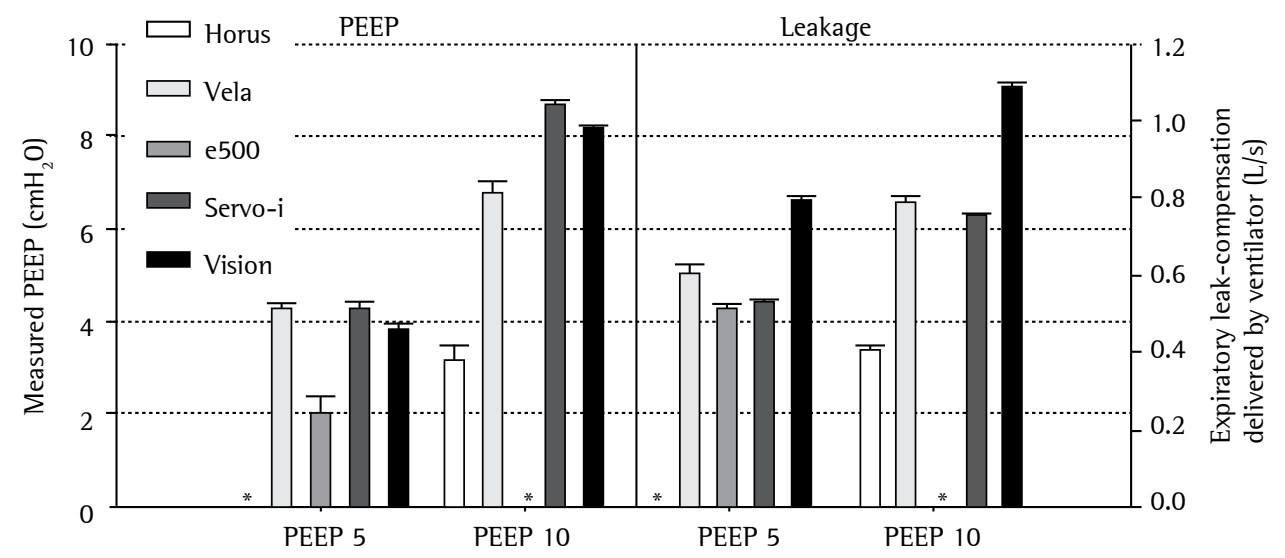

Figure 2 - Measured positive end-expiratory pressure (PEEP; left panel) and expiratory flow delivered by the ventilator (right panel) to compensate for air leakage at PEEP of $5 \mathrm{cmH}_{2} \mathrm{O}$ (PEEP5) and $10 \mathrm{cmH}_{2} \mathrm{O}$ (PEEP10), expressed as mean \pm SD. As shown, the Horus and the e500 ventilators did not compensate adequately for leaks, delivering less than $0.6 \mathrm{~L} / \mathrm{s}$ of compensatory flow, and were not capable of keeping the set PEEP level. ${ }^{*}$ Not measured due to autotriggering. 
Regarding tidal volumes, they became higher with the increase in pressure support levels (Figure E3, available online at http://www.jornaldepneumologia. com.br/imagebank/images/jbp_v40n3_suplemment. pdf). The mean tidal volumes for all ventilators using PEEP5 at PS5, PS10, and PS15 were 472 $\pm 25 \mathrm{~mL}, 609 \pm 32 \mathrm{~mL}$, and $726 \pm 124 \mathrm{~mL}$, respectively, whereas the mean tidal volumes for the ventilators using PEEP10 at the same three pressure support modes were $489 \pm 25 \mathrm{~mL}, 641$ $\pm 28 \mathrm{~mL}$, and $768 \pm 90 \mathrm{~mL}$, respectively.

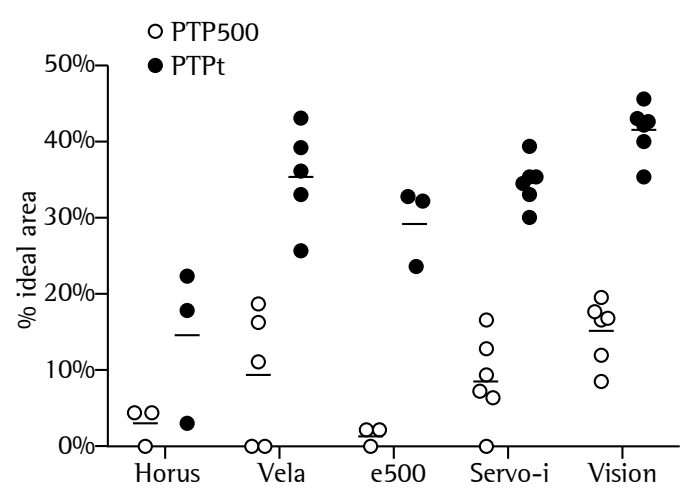

Figure 3 - Pressurization characteristics of five of the ventilators tested, demonstrated by inspiratory pressuretime product at $500 \mathrm{~ms}$ (PTP500; open circles) and at $1 \mathrm{~s}$ (PTPt; filled circles), expressed in percentage of ideal area. The horizontal dashes indicate the means of all measures (positive end-expiratory pressures of 5 and $10 \mathrm{cmH}_{2} \mathrm{O}$ vs. pressure support of 5, 10 and $15 \mathrm{cmH}_{2} \mathrm{O}$ ) available for the ventilators.
The mechanical lung model (without the test ventilators) had an intrinsic baseline delay of 30.5 $\mathrm{ms}$ and $24.9 \mathrm{~ms}$, respectively, for trigger delay and cycling-off delay. Only the e500 and Horus presented with trigger delay values higher than 100 ms (276 $\pm 105 \mathrm{~ms}$ and $152 \pm 36 \mathrm{~ms}$, respectively). The Servo-i, Vela, and BiPAP Vision, respectively, had trigger delay values of $50 \pm 12 \mathrm{~ms}, 53 \pm 6$ $\mathrm{ms}$, and $69 \pm 27 \mathrm{~ms}$ (Figure E4, available online at http://www.jornaldepneumologia.com.br/ imagebank/images/jbp_v40n3_suplemment.pdf). Neither PEEP nor pressure support altered the triggering delay. Although the Servo-i ventilator had the lowest cycling-off delay $(8.5 \pm 67 \mathrm{~ms})$, it presented with premature cycling in some settings ( -94 ms for PEEP5 at PS5, as well as $-43 \mathrm{~ms}$ for PEEP10 at PS5). The BiPAP Vision ventilator had a mean cycling-off delay of $136 \pm$ $92 \mathrm{~ms}$. The Horus and Vela had mean values of $273 \pm 231 \mathrm{~ms}$ and $228 \pm 214 \mathrm{~ms}$, respectively. In both, cycling sometimes occurred by reaching the adjusted maximum inspiratory time of $1.5 \mathrm{~s}$. The e500 ventilator showed the highest cycling-off delay (590 $\pm 622 \mathrm{~ms}$; Figure E5, available online at http://www.jornaldepneumologia.com.br/ imagebank/images/jbp_v40n3_suplemment.pdf).

\section{Discussion}

The most important finding in the present study was that only one of the tested ICU ventilators was suitable for NIV using a TFM.

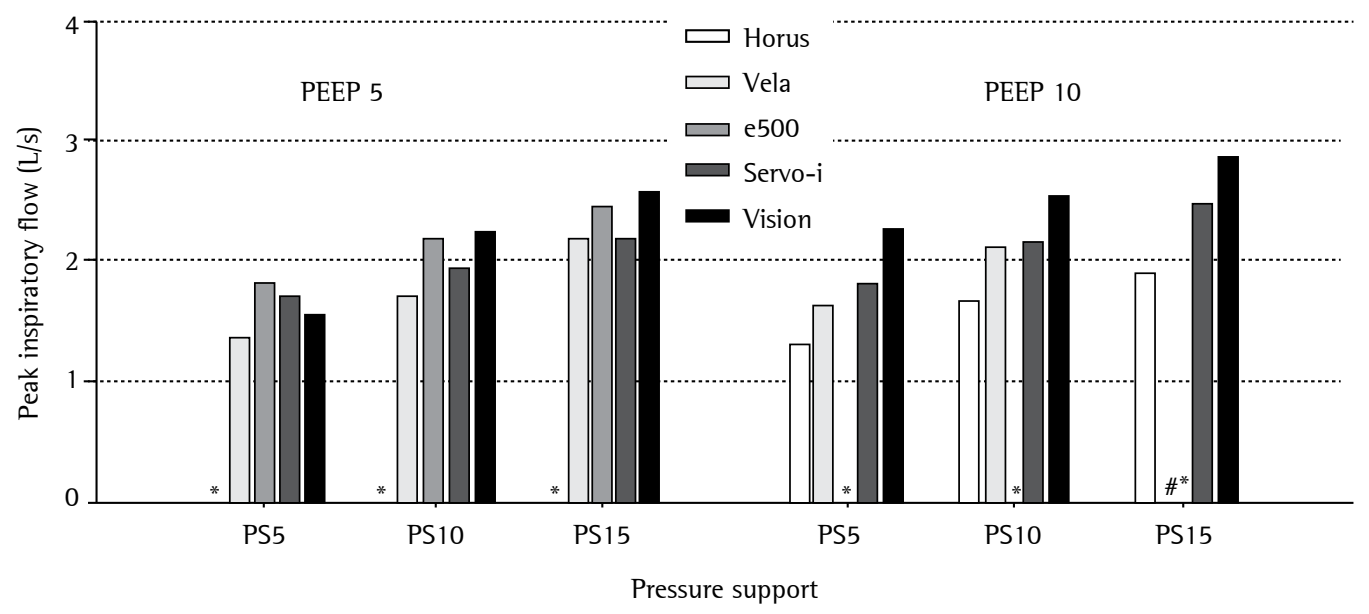

Figure 4 - Peak inspiratory flow of five of the ventilators tested. Measurements with positive end-expiratory pressure of $5 \mathrm{cmH}_{2} \mathrm{O}$ (PEEP5) and $10 \mathrm{cmH}_{2} \mathrm{O}$ (PEEP10) are on the left and right sides, respectively. The measurements were taken at pressure support levels of 5, 10, and $15 \mathrm{cmH}_{2} \mathrm{O}$ (PS5, PS10, and PS15, respectively). *The Horus ventilator at PEEP5 and the e500 ventilator at PEEP10 were not measured due to autotriggering. "Because of the limitation of the lung model, the Vela ventilator was not tested for PEEP10 with PS15. 
Of the eight ICU ventilators, four were considered totally non-operational due to inappropriate turning-off (misinterpretation of disconnection) or autotriggering, whereas three of the remaining four had problems to compensate for the large leaks through the exhalation ports, resulting in inability to keep PEEP and inspiratory pressure, delayed inspiratory triggering, or delayed inspirationto-expiration cycling. Only the Servo-i and the control NIV ventilator (BiPAP Vision) worked properly under all experimental conditions. It is important to emphasize that, in the absence of significant system leakage (sealed oronasal mask), all ventilators worked well (data not shown).

It is expected that TFMs cause large air leaks through their built-in orifices, which can sometimes be of a magnitude comparable to that of a patient disconnection. To increase safety, various manufacturers have limited the leak compensation for $\mathrm{ICU}$ ventilators to values equal to or lower than $30 \mathrm{~L} / \mathrm{min}$ (or $0.5 \mathrm{~L} / \mathrm{s}$ ), ${ }^{(16)}$ values above which the disconnection alarm of the ventilator goes off. In our study, the mean expiratory leak for the three ventilators that were able to maintain PEEP levels (Servo-i, Vela, and BiPAP Vision) was $45.6 \pm 10.8 \mathrm{~L} / \mathrm{min}$ with the smallest PEEP value (PEEP5), which is greater than when an oronasal mask is used..$^{(17)}$ These large air leaks most likely explain why four of the eight ventilators were considered non-operational.

Similar findings have been described previously. Miyoshi et al. ${ }^{(11)}$ tested two ICU ventilators and reported that both worked properly with leaks up to $11.3 \mathrm{~L} / \mathrm{min}$; however, autotriggering and shutdown of the inspiratory flow occurred with leaks larger than $18 \mathrm{~L} / \mathrm{min}$. Another bench study, using an oronasal face mask and three customized leaks, compared nine ICU ventilators equipped with NIV mode and one NIV ventilator (BiPAP Vision). ${ }^{(16)}$ When the air leak was increased to 37 $\mathrm{L} / \mathrm{min}$, only one ICU ventilator (Servo-i) and the NIV ventilator worked properly without adjustments, whereas four ICU ventilators either went to backup ventilation or were unable to synchronize. ${ }^{(16)}$

In our study, the e500 and the Horus ventilators were not able to maintain PEEP values with air leaks close to $30 \mathrm{~L} / \mathrm{min}$ (or $0.5 \mathrm{~L} / \mathrm{s}$ ). Other authors have recognized the importance of the leak magnitude for PEEP maintenance. ${ }^{(18,19)}$

Usually, the inspiratory pressurization is evaluated by the PTP within the first $300 \mathrm{~ms}$ or $500 \mathrm{~ms}$
(PTP300 and PTP500, respectively), because PIF is reached within the first 250-300 ms and the level of pressure support is reached, in most ventilators, within the first $500 \mathrm{~ms}^{(20)}$ Due to the magnitude of the air leak found in our study, pressurization was delayed and PTP300 values were very low, rendering this measurement inappropriate for the evaluation of the quality of pressurization. We therefore chose PTP500 and PTPt as the indices of pressurization. Using these variables, we found that the pressurization capacity in the presence of air leaks varied widely among the ventilators, even after reaching the optimal setting of inspiratory pressure slope. This finding is in agreement with those in previous studies. ${ }^{(18,19)}$

Given the importance of the inspiratory pressure slope on the pressurization capacity, it has been suggested that slope adjustment should be automated for better performance. ${ }^{(21)}$ Unexpectedly, the two ventilators with automatic adjustment of slope (e500 and Vela) were outperformed by Servo-i and BiPAP Vision in their ability to maintain pressurization. Nevertheless, it is true that the e500 showed the highest PIF and PIP, and it was the pressure loss during the expiratory phase that hindered its capacity to achieve optimal pressurization.

The trigger delay was smallest in the Servo-i, Vela, and BiPAP Vision. The ventilators that had the greatest difficulty in compensating for air leakage during the expiratory phase (e500 and Horus) were the ones with the highest trigger delays. Leaks in a suboptimally compensated ventilatory system can interfere with the synchrony between the patient and the ventilator because the ventilator relies on monitored pressure and flow in order to trigger each breath, and air leaks can change these signals. Delays of a magnitude similar to our findings were reported in an evaluation of portable ventilators with two pressure levels in a model with small inspiratory leaks (maximum of $0.16 \mathrm{~L} / \mathrm{s}) .{ }^{(22)}$

In pressure support mode, the ventilator cycles from inspiration to expiration when the inspiratory flow decreases to a given value or, in most cases, to a proportion of PIF. When the ventilator cannot end the inspiration by this criterion, cycling-off occurs by secondary criteria, usually an upper limit threshold for the inspiratory time. ${ }^{(23)}$ In our study, this backup criterion served as the primary mechanism under conditions of high pressures and large air leaks in the Horus, 
Vela, and e500. Limitations of the cycling-off criteria in ICU ventilators in the presence of air leakage were previously reported, ${ }^{(24)}$ but this problem has been amended in new software versions of some ventilators and new ventilator models $^{(25)}$ (see footnotes in Table 1).

Of all tested ICU ventilators, only Servo-i had an acceptable performance with TFM, although it is noteworthy to mention that, in some settings, premature cycling occurred, a finding previously reported regarding this ventilator. ${ }^{(26)}$ The use of TFM with the other ICU ventilators led to considerable asynchrony that would likely cause excessive patient discomfort and noncompliance with NIV. In addition, some ventilators did not offer sufficient assistance to satisfy the demands of the model, and this fact might potentially increase the respiratory muscle load and worsen respiratory failure in a clinical setting.

These findings suggest that, in order to adequately handle the air leaks that occur with the TFM, manufacturers will have to improve the algorithms in ICU ventilators, ${ }^{(27)}$ allowing the reset of the upper limit of flow compensation, which is already true for some ventilators (see footnotes in Table 1). Because this type of software change might have safety implications (disconnection alarm), one possible solution would be to implement an adjustable upper limit of flow based on whether the patient is connected to a TFM or not. Another important consequence of air leaks, which can get higher than $1.7 \mathrm{~L} / \mathrm{s}(100 \mathrm{~L} / \mathrm{min})$ in some instances, is the extra cost of wasted medical gases, especially with the use of high fractions of inspired oxygen. To overcome this problem, the true need of such large proximal leaks when using TFMs should be investigated as a mathematical model, and bench studies have shown that the dead space of a TFM is smaller than is its internal volume. ${ }^{(28,29)}$

Recently, new NIV interfaces (PerforMax and Fitlife; Philips Respironics) ${ }^{(30)}$ have been marketed with similar characteristics but smaller internal volumes and without the two bores in the mask that act as exhalation valves. These interfaces use two types of elbow: a standard elbow for use with ICU ventilators without air leakage and an entrainment elbow for NIV ventilators. However, it remains unknown whether the use of these masks without leaks (standard elbows) would result in adequate alveolar ventilation even if they were attached to invasive mechanical ventilators (which have separate inspiratory and expiratory limbs). For example, in one report, patients required a high minute ventilation to avoid $\mathrm{CO}_{2}$ retention when using a TFM without significant leaks. ${ }^{(31)}$ In conditions in which high tidal volumes are considered inappropriate, one possible solution would be to combine the use of the entrainment elbow (with leaks) with invasive mechanical ventilators, thus optimizing $\mathrm{CO}_{2}$ washout.

Some limitations of this study should be outlined. First, this is a bench study, and the results should be extrapolated for clinical practice with caution. Second, due to the large air leakage in the system, the ventilators had to generate high inspiratory flows, causing a significant pressure drop, as measured with the pneumotachograph (placed between the ventilator and the proximal pressure transducer), which led to a slight underestimation of the proximal pressures. However, although it was not possible to precisely estimate the absolute values of PEEP, PIP, and PTP produced in the ventilator circuit, it was possible to compare the ventilators. In addition, because the values of PEEP were inferior to the value generated by the ventilator, the expiratory leakage was likely to be a little higher than that measured. Finally, some ventilators or their NIV modes have been updated (see footnotes in Table 1) after the present study was conducted, and these changes might have affected their performances.

In conclusion, due to the large air leaks associated with the use of TFMs, the majority of the ICU ventilators tested were not suitable for NIV with TFMs.

\section{Acknowledgements}

The authors would like to thank the manufacturers of ventilators tested for providing them gratuitously.

\section{References}

1. Garpestad E, Brennan J, Hill NS. Noninvasive ventilation for critical care. Chest. 2007;132(2):711-20. http:// dx.doi.org/10.1378/chest.06-2643

2. Schettino G, Altobelli N, Kacmarek RM. Noninvasive positive-pressure ventilation in acute respiratory failure outside clinical trials: experience at the Massachusetts General Hospital. Crit Care Med. 2008;36(2):441-7. http://dx.doi.org/10.1097/01.CCM.0000300084.67277.90

3. Carlucci A, Richard JC, Wysocki M, Lepage E, Brochard L; SRLF Collaborative Group on Mechanical Ventilation. Noninvasive versus conventional mechanical ventilation. 
An epidemiologic survey. Am J Respir Crit Care Med. 2001;163(4):874-80. http://dx.doi.org/10.1164/ ajrccm.163.4.2006027

4. Mehta S, Hill NS. Noninvasive ventilation. Am J Respir Crit Care Med. 2001;163(2):540-77. http://dx.doi. org/10.1164/ajrccm.163.2.9906116

5. Criner GJ, Travaline JM, Brennan KJ, Kreimer DT. Efficacy of a new full face mask for noninvasive positive pressure ventilation. Chest. 1994;106(4):1109-15. http://dx.doi. org/10.1378/chest.106.4.1109

6. Holanda MA, Reis RC, Winkeler GF, Fortaleza SC, Lima JW, Pereira ED. Influence of total face, facial and nasal masks on short-term adverse effects during noninvasive ventilation. J Bras Pneumol. 2009;35(2):164-73. http:// dx.doi.org/10.1590/S1806-37132009000200010

7. Ozsancak A, Sidhom SS, Liesching TN, Howard W, Hill NS. Evaluation of the total face mask for noninvasive ventilation to treat acute respiratory failure. Chest. 2011;139(5):1034-41. http://dx.doi.org/10.1378/ chest.10-1905

8. Schettino GP, Chatmongkolchart S, Hess DR, Kacmarek RM. Position of exhalation port and mask design affect CO2 rebreathing during noninvasive positive pressure ventilation. Crit Care Med. 2003;31(8):2178-82. http:// dx.doi.org/10.1097/01.CCM.0000081309.71887.E9

9. Roy B, Cordova FC, Travaline JM, D'Alonzo GE Jr, Criner GJ. Full face mask for noninvasive positive-pressure ventilation in patients with acute respiratory failure. J Am Osteopath Assoc. 2007;107(4):148-56.

10. Cuvelier A, Pujol W, Pramil S, Molano LC, Viacroze C, Muir JF. Cephalic versus oronasal mask for noninvasive ventilation in acute hypercapnic respiratory failure. Intensive Care Med. 2009;35(3):519-26. http://dx.doi. org/10.1007/s00134-008-1327-x

11. Miyoshi E, Fujino Y, Uchiyama A, Mashimo T, Nishimura M. Effects of gas leak on triggering function, humidification, and inspiratory oxygen fraction during noninvasive positive airway pressure ventilation. Chest. 2005;128(5):3691-8. http://dx.doi.org/10.1378/chest.128.5.3691

12. Schettino GP, Tucci MR, Sousa R, Valente Barbas CS, Passos Amato MB, Carvalho CR. Mask mechanics and leak dynamics during noninvasive pressure support ventilation: a bench study. Intensive Care Med. 2001;27(12):1887-91. http://dx.doi.org/10.1007/s00134-001-1146-9

13. Lucato JJ, Tucci MR, Schettino GP, Adams AB, Fu C, Forti G Jr, et al. Evaluation of resistance in 8 different heat-and-moisture exchangers: effects of saturation and flow rate/profile. Respir Care. 2005;50(5):636-43.

14. Fu C, Caruso P, Lucatto JJ, de Paula Schettino GP, de Souza R, Carvalho CR. Comparison of two flow generators with a noninvasive ventilator to deliver continuous positive airway pressure: a test lung study. Intensive Care Med. 2005;31(11):1587-91. http://dx.doi. org/10.1007/s00134-005-2795-x

15. Bland JM, Altman DG. Measurement error. BMJ. 1996;313(7059):744. http://dx.doi.org/10.1136/ bmj.313.7059.744

16. Ferreira JC, Chipman DW, Hill NS, Kacmarek RM. Bilevel vs ICU ventilators providing noninvasive ventilation: effect of system leaks: a COPD lung model comparison. Chest. 2009;136(2):448-56. http://dx.doi.org/10.1378/ chest.08-3018

17. Louis B, Leroux K, Isabey D, Fauroux B, Lofaso F. Effect of manufacturer-inserted mask leaks on ventilator performance. Eur Respir J. 2010;35(3):627-36. http:// dx.doi.org/10.1183/09031936.00188708

18. Vignaux L, Tassaux D, Jolliet P. Performance of noninvasive ventilation modes on ICU ventilators during pressure support: a bench model study. Intensive Care Med. 2007;33(8):1444-51. http://dx.doi.org/10.1007/ s00134-007-0713-0

19. Mehta S, McCool FD, Hill NS. Leak compensation in positive pressure ventilators: a lung model study. Eur Respir J. 2001;17(2):259-67. http://dx.doi.org/10.118 3/09031936.01.17202590

20. Tassaux D, Strasser S, Fonseca S, Dalmas E, Jolliet P. Comparative bench study of triggering, pressurization, and cycling between the home ventilator VPAP 11 and three ICU ventilators. Intensive Care Med. 2002;28(9):1254-61. http://dx.doi.org/10.1007/s00134-002-1421-4

21. Chatmongkolchart S, Williams P, Hess DR, Kacmarek RM. Evaluation of inspiratory rise time and inspiration termination criteria in new-generation mechanical ventilators: a lung model study. Respir Care. 2001;46(7):666-77.

22. Battisti A, Tassaux D, Janssens JP, Michotte JB, Jaber $\mathrm{S}$, Jolliet P. Performance characteristics of 10 home mechanical ventilators in pressure-support mode: a comparative bench study. Chest. 2005;127(5):1784-92. http://dx.doi.org/10.1378/chest.127.5.1784

23. Yamada Y, Du HL. Effects of different pressure support termination on patient-ventilator synchrony. Respir Care. 1998;43(12):1048-057.

24. Calderini E, Confalonieri M, Puccio PG, Francavilla N, Stella L, Gregoretti C. Patient-ventilator asynchrony during noninvasive ventilation: the role of expiratory trigger. Intensive Care Med. 1999;25(7):662-7. http:// dx.doi.org/10.1007/s001340050927

25. Carteaux G, Lyazidi A, Cordoba-lzquierdo A, Vignaux L, Jolliet $\mathrm{P}$, Thille AW, et al. Patient-ventilator asynchrony during noninvasive ventilation: a bench and clinical study. Chest. 2012;142(2):367-76. http://dx.doi.org/10.1378/ chest.11-2279

26. Vignaux L, Tassaux D, Carteaux G, Roeseler J, Piquilloud L, Brochard $\mathrm{L}$, et al. Performance of noninvasive ventilation algorithms on ICU ventilators during pressure support: a clinical study. Intensive Care Med. 2010;36(12):2053-9. http://dx.doi.org/10.1007/s00134-010-1994-2

27. Hess DR. Patient-ventilator interaction during noninvasive ventilation. Respir Care. 2011;56(2):153-65; discussion 65-7. http://dx.doi.org/10.4187/respcare.01049

28. Fodil R, Lellouche F, Mancebo J, Sbirlea-Apiou G, lsabey $\mathrm{D}$, Brochard L, et al. Comparison of patient-ventilator interfaces based on their computerized effective dead space. Intensive Care Med. 2011;37(2):257-62. http:// dx.doi.org/10.1007/s00134-010-2066-3

29. Saatci E, Miller DM, Stell IM, Lee KC, Moxham J. Dynamic dead space in face masks used with noninvasive ventilators: a lung model study. Eur Respir J. 2004;23(1):129-35. http://dx.doi.org/10.1183/09031936.03.00039503

30. Belchior 1, Gonçalves MR, Winck JC. Continuous noninvasive ventilation delivered by a novel total face mask: a case series report. Respir Care. 2012;57(3):44953. http://dx.doi.org/10.4187/respcare.01275

31. Fraticelli AT, Lellouche F, L'her E, Taillé S, Mancebo J, Brochard L. Physiological effects of different interfaces during noninvasive ventilation for acute respiratory failure. Crit Care Med. 2009;37(3):939-45. http://dx.doi. org/10.1097/CCM.0b013e31819b575f 
Performance of ICU ventilators during noninvasive ventilation

with large leaks in a total face mask: a bench study

\section{About the authors}

\section{Maria Aparecida Miyuki Nakamura}

Research Physical Therapist. Laboratório de Investigação Médica 09 (LIM 09, Laboratory for Medical Research 09), Department of Pulmonology, Heart Institute, University of São Paulo School of Medicine Hospital das Clínicas, São Paulo, Brazil.

\section{Eduardo Leite Vieira Costa}

Physician. Respiratory 1CU, Department of Pulmonology, Heart Institute, University of São Paulo School of Medicine Hospital das Clínicas; and Researcher, Instituto de Ensino e Pesquisa, Hospital Sírio-Libanês, São Paulo, Brazil.

\section{Carlos Roberto Ribeiro Carvalho}

Full Professor of Pulmonology. Department of Cardiorespiratory Diseases, University of São Paulo School of Medicine, São Paulo, Brazil.

\section{Mauro Roberto Tucci}

Research Physician. Laboratório de Investigação Médica 09 (LIM 09, Laboratory for Medical Research 09), Department of Pulmonology, Heart Institute, University of São Paulo School of Medicine Hospital das Clínicas, São Paulo, Brazil. 


\section{0ñline swipilement}

Table E1 - Main characteristics of the ventilators tested. ${ }^{\text {a }}$

\begin{tabular}{|c|c|c|c|c|c|c|}
\hline Ventilator & $\begin{array}{l}\text { Ventilator } \\
\text { type }\end{array}$ & $\begin{array}{l}\text { NIV mode } \\
\text { equipped }\end{array}$ & Trigger & $\begin{array}{c}\text { Slope/ } \\
\text { rise time }\end{array}$ & $\begin{array}{l}\text { Expiratory } \\
\text { sensitivity }\end{array}$ & Other characteristics \\
\hline BiPAP Vision & $\begin{array}{l}\text { NIV } \\
\text { mode only }\end{array}$ & ------- & Automatic & $\begin{array}{l}\text { IPAP rise time: } \\
0.05-0.40 \mathrm{~s}\end{array}$ & Automatic & $\begin{array}{l}\text { Leak compensation } \\
\text { up to } 60 \mathrm{~L} / \mathrm{min}\end{array}$ \\
\hline Puritan Bennett 840 & ICUV & YES & $\begin{array}{l}F: 0.5-20.0 \\
P: 0.1-20.0\end{array}$ & $10-100 \%$ & $1-45 \%$ & $\begin{array}{l}\text { DS: } 95-20 \% \text {, } \\
\text { or turned off }\end{array}$ \\
\hline Savina & ICUV & YES & F: $1-15$ & $\begin{array}{c}5-200 \\
\mathrm{cmH}_{2} \mathrm{O} / \mathrm{s}\end{array}$ & Fixed: $25 \%$ & $\begin{array}{l}\text { Leak compensation } \\
\text { up to } 25 \mathrm{~L} / \mathrm{min}\end{array}$ \\
\hline GALILEO Gold & ICUV & YES & $\begin{array}{l}\text { F: } 0.5-15.0 \\
\text { P: } 0.5-10.0\end{array}$ & $25-200 \mathrm{~ms}$ & $5-70 \%$ & Base flow: 4-30 L/min \\
\hline Servo-i & ICUV & YES & $\begin{array}{c}\text { F: } 0-100 \% \\
\text { bias flow } \\
\text { P: } 0-20 \\
\text { Automatic }\end{array}$ & $0-0.4 \mathrm{~s}$ & $1-40 \%$ & $\begin{array}{l}\text { Bias flow: } 2 \mathrm{~L} / \mathrm{min} \\
\text { Leak compensation } \\
\text { up to } 50 \mathrm{~L} / \mathrm{min}\end{array}$ \\
\hline e500 & ICUV & YES & $\begin{array}{l}F: 0.6-2.0 \\
P: 0-5\end{array}$ & $\begin{array}{l}\text { 1-20 AU or } \\
\text { automatic }\end{array}$ & $5-55 \%$ & $\begin{array}{l}\text { Leak compensation } \\
\text { up to } 25 \mathrm{~L} / \mathrm{min}\end{array}$ \\
\hline Esprit & ICUV & YES & F: $0.5-20.0$ & $0.1-0.9 \mathrm{~s}$ & $10-45 \%$ & \\
\hline Horus & ICUV & YES & $\begin{array}{l}F: 0.1-5.0 \\
P: 0.5-5.0\end{array}$ & $\begin{array}{l}50-150 \\
\mathrm{cmH}_{2} \mathrm{O} / \mathrm{s}\end{array}$ & $0-30 \mathrm{~L}$ & $\begin{array}{l}\text { Leak compensation } \\
\text { up to } 30 \mathrm{~L} / \mathrm{min}\end{array}$ \\
\hline Vela & ICUV & YES & $\begin{array}{c}\text { F: } 1-8 \\
\text { Automatic }\end{array}$ & Automatic & $5-30 \%$ & Bias flow: $10-20 \mathrm{~L} / \mathrm{min}$ \\
\hline
\end{tabular}

NIV: noninvasive ventilation; IPAP: inspiratory positive airway pressure; ICUV: intensive care unit ventilator; F: flow sensitivity (L/min); P: pressure sensitivity $\left(\mathrm{cmH}_{2} \mathrm{O}\right)$; AU: arbitrary unit; and DS: disconnection sensitivity. ${ }^{2}$ BiPAP Vision (Philips Respironics, Murryville, PA, USA); Puritan Bennett 840 (Covidien, Boulder, CO, USA); Savina (Drägerwerk AG Et Co., Lübeck, Germany); GAllLE0 Gold (Hamilton Medical, Rhäzuns, Switzerland); Servo-i (Maquet, Solna, Sweden); e500 (Newport Medical Instruments, Costa Mesa, CA, USA); Esprit (Philips Respironics); Horus (Taëma, Anthony, France); and Vela (Viasys Healthcare, Palm Springs, CA, USA).

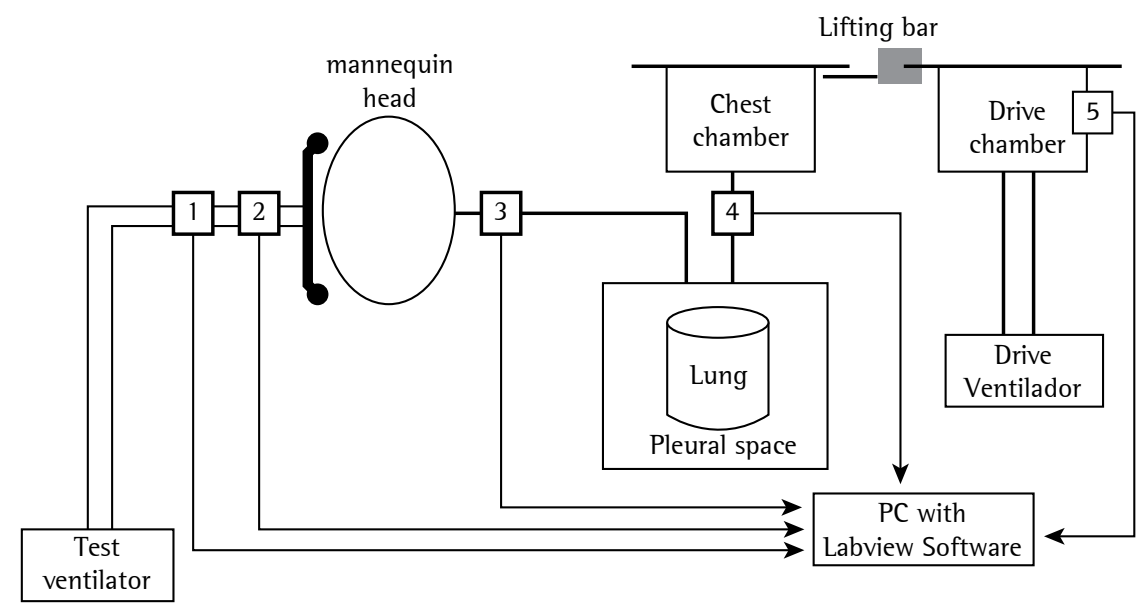

Figure E1 - Schematic representation of the lung model. Flow and pressure transducers are identified by numbers: (1) proximal flow transducer; (2) proximal pressure transducer; (3) distal flow transducer; (4) pleural pressure transducer; and (5) pressure transducer inside the drive chamber (drive pressure transducer). 


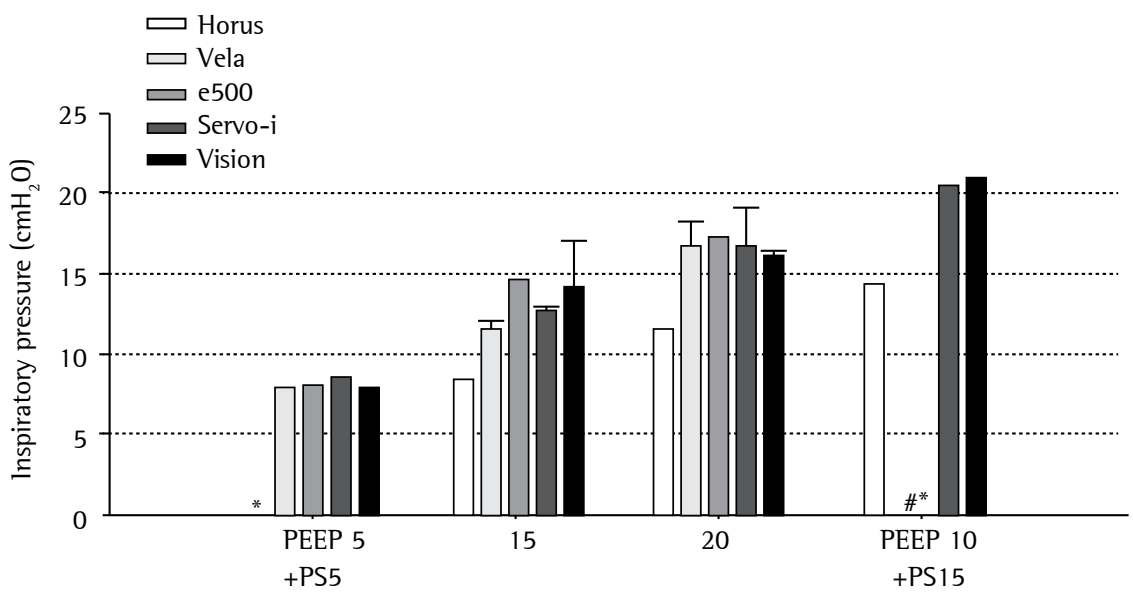

Figure E2 - Proximal inspiratory pressure of five of the ventilators tested. For simplicity, situations with same total pressure-sum of positive end-expiratory pressure at $5 \mathrm{cmH}_{2} \mathrm{O}$ (PEEP5) or $10 \mathrm{cmH}_{2} \mathrm{O}$ (PEEP10) and pressure support (PS) levels of 5 or $15 \mathrm{cmH} 20$ (PS5 and PS15, respectively)-were grouped together. *The Horus ventilator at PEEP5 and the e500 ventilator at PEEP10 were not measured due to autotriggering. "Because of the limitation of the lung model, the Vela ventilator was not tested for PEEP10 with PS15.

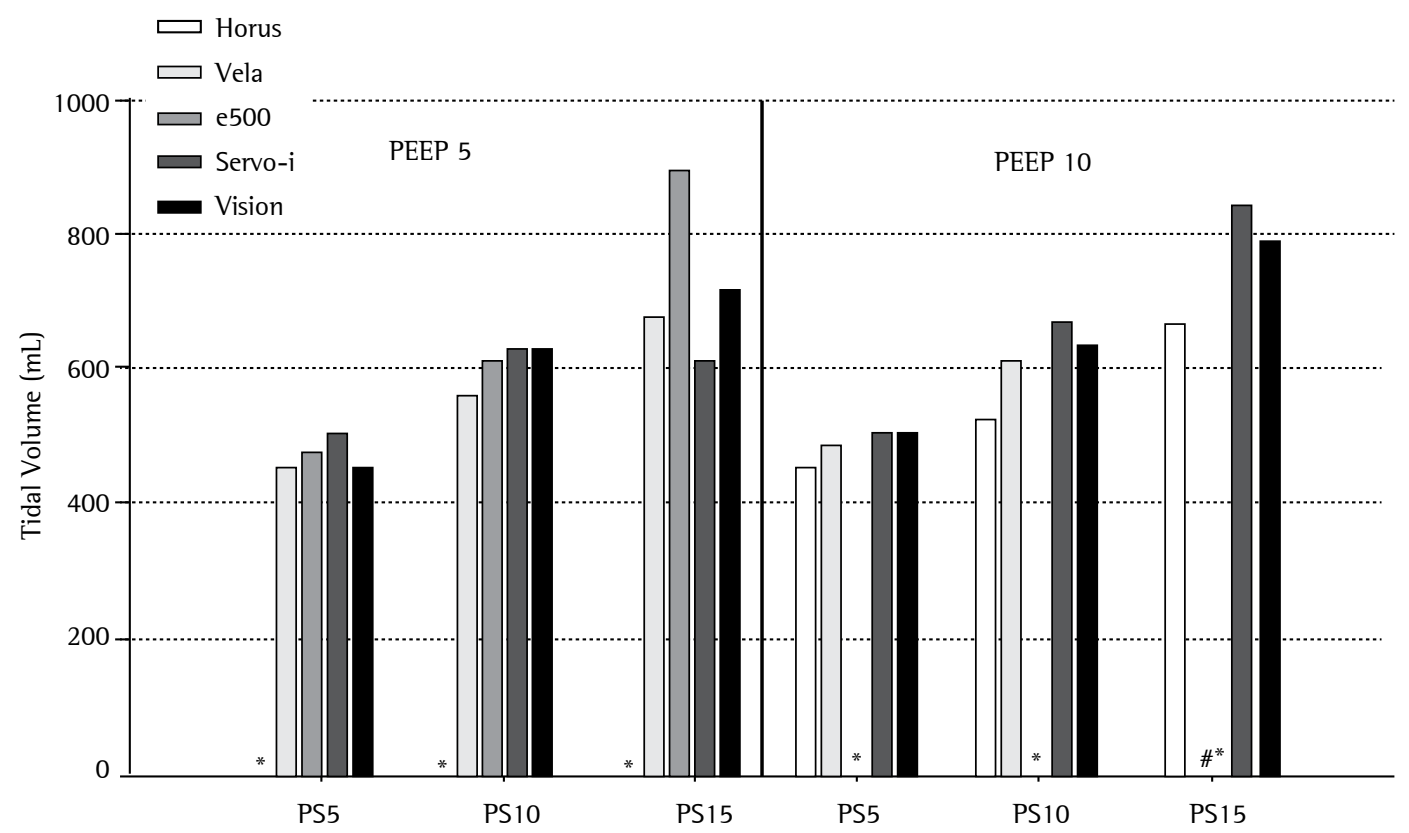

Figure E3 - Tidal volume of five of the ventilators tested. Measurements at pressure support levels of 5, 10, and $15 \mathrm{cmH}_{2} \mathrm{O}$ (PS5, PS10, and PS15, respectively) are on the left and the right sides for positive end-expiratory pressures of $5 \mathrm{cmH}_{2} \mathrm{O}$ (PEEP5) and of $10 \mathrm{cmH}_{2} \mathrm{O}$ (PEEP10), respectively. *The Horus ventilator at PEEP5 and the e500 ventilator at PEEP10 were not measured due to autotriggering. "Because of the limitation of the lung model, the Vela ventilator was not tested for PEEP10 with PS15. 


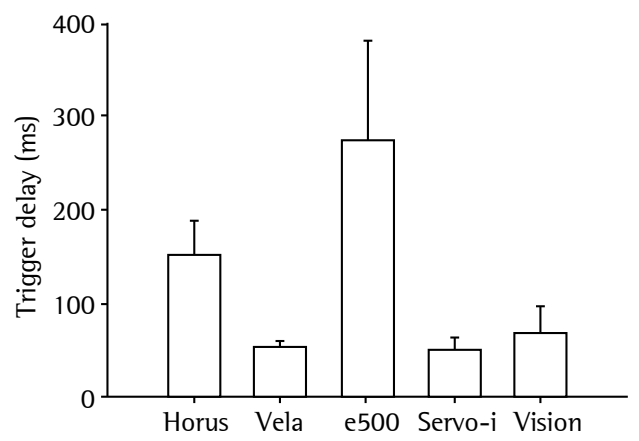

Figure E4 - Trigger delay of five of the ventilators tested. Note: for the calculation of the means \pm SD, the number of the conditions tested-positive end-expiratory pressure of 5 and $10 \mathrm{cmH}_{2} \mathrm{O}$ (PEEP5 and PEEP10, respectively)] using pressure support of 5, 10, and $15 \mathrm{cmH}_{2} \mathrm{O}$ (PS5, PS10, and PS15, respectively)-varied with the ventilator tested. Horus: three conditions (PEEP10 vs. PS5, PS10 and PS15); Vela: five conditions (PEEP5 vs. PS5, PS10 and PS15; and PEEP10 vs. PS5 and PS10); e500: three conditions (PEEP5 vs. PS5, PS10 and PS15); and Servo-i and BiPAP Vision: all six conditions.

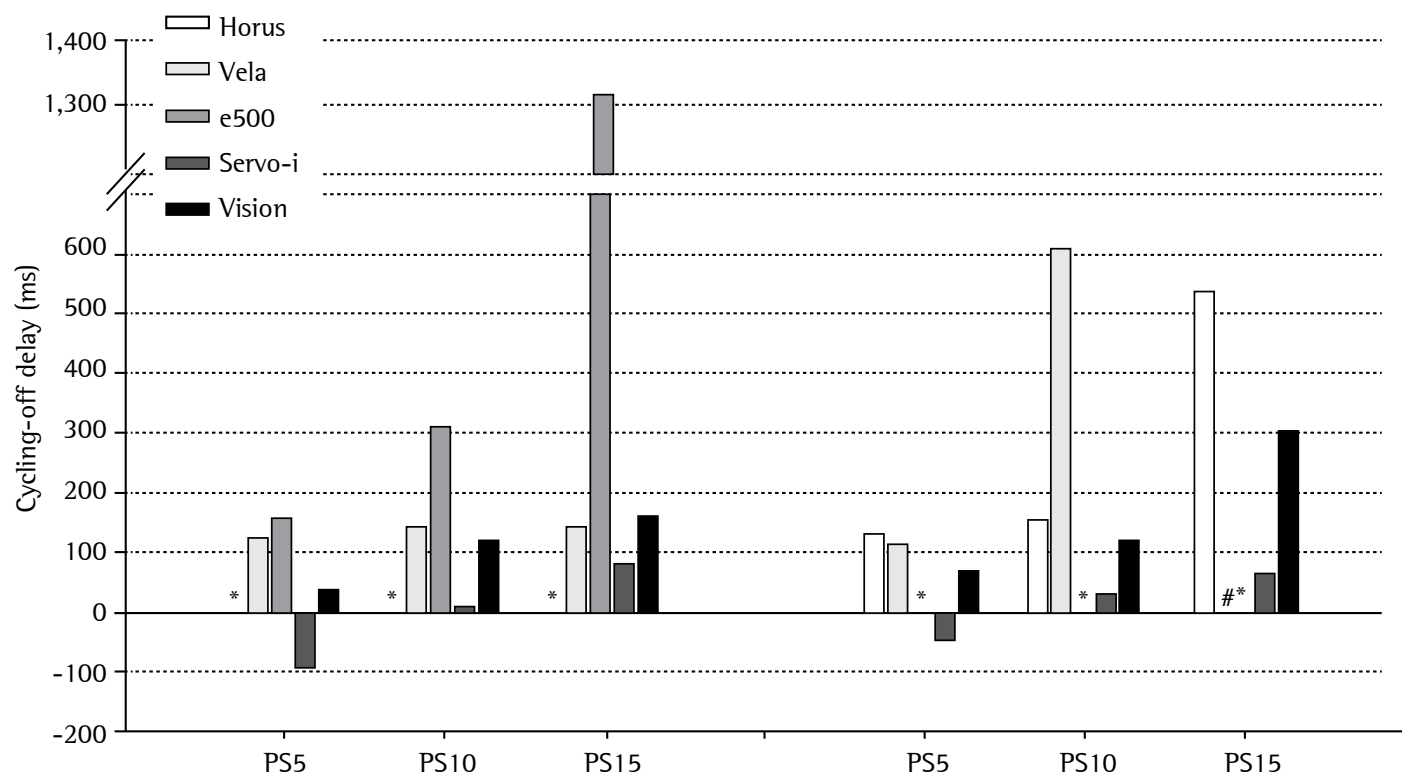

Figure E5 - Cycling-off delay of five of the ventilators tested. Positive values represent excessive duration of mechanical assistance from the ventilator, whereas negative values represent insufficient duration of mechanical assistance from the ventilator (premature cycling). PEEP5 and PEEP10: positive end-expiratory pressure of 5 and $10 \mathrm{cmH}_{2} \mathrm{O}$, respectively; and PS5, PS10, and PS15: pressure support of 5, 10, and 15 $\mathrm{cmH}_{2} \mathrm{O}$, respectively. 